\title{
STAGING CLIMATE SECURITY: Resilience and Heterodystopia in the Bangladesh Borderlands
}

\author{
JASON CONS \\ University of Texas at Austin \\ (iD) http: / / orcid.org/0000-0003-1869-527X
}

In the spring of 2015, while working in the countryside of Munshiganj in the borderlands of southwestern Bangladesh, ${ }^{1}$ my colleague and I came across a strange and visually striking project rising incongruously from the flat delta landscape. ${ }^{2}$ It was an earthen mound, or mattir killa, meant to be used as a storm shelter. The mound was fourteen feet in height and a half-acre in size. It had been constructed in 2011 in the aftermath of Cyclone Aila, which caused widespread infrastructural damage and displacement throughout the region in 2009. The killa was built by a local NGO, Shushilon, and financed by Christian Aid, an international NGO. ${ }^{3}$ It formed part of a vast wave of new projects in the region to address disaster preparedness and climate change following Aila. What seemed strange about the project was not only its visual appearance, climbing abruptly from its otherwise horizontal surroundings, but its stated purpose: what kind of shelter could this raised mound provide? In contrast to the concrete cyclone shelters that dot the region, the killa seemed to offer limited protection. Moreover, though nominally a public good, it had been built on private land. Striking up a conversation with the farmer who owned the land and whose home stood in the killa's shadow, we asked about the project and its uses. He lived some distance from the nearest cyclone shelter, so when the storms came, he claimed, of journal content for the above purposes should credit the author and original source. Use, reproduction, or distribution of journal content for commercial purposes requires additional permissions from the American Anthropological Association; please contact permissions@americananthro.org.DOI: 10.14506/ca33.2.08 
his family and livestock sheltered on the killa. But, he also added, "In the future, when we are surrounded by water, the children will go up there to live.”

The farmer's statements offered a troubling vision of climate change as a future of disaster in which (some) families would survive on earthen plinths as catastrophe unfolded around them. As I will argue here, this statement mirrored an emergent logic of development intervention in the region - an imagining of an atomized family surviving the ravages of climate change alone, assisted primarily by development technology. In this essay, I critically engage this imagination. To do so, I consider interventions such as the killa, their situation in the India-Bangladesh borderlands, and their relations to broader discourses, anticipations, and anxieties about climate security. I argue that these projects are best understood as spaces managed as and in anticipation of a world of dystopian climate crisis. As such, these projects function as stages for future interventions and present-day spectacles of climate security. In other words, these projects advance a logic of managing and planning for future climatological disaster that both attempts to produce resilient life in a warming world and displays strategies of containment for audiences elsewhere. We might call these spaces, following Michel Foucault (1998), heterodystopias - a term I offer as a means to analytically diagnose the relationships between these projects and imaginations of a dystopian future to come.

Despite a rapidly growing body of anthropological work on climate change, so far little work has interrogated the ways in which the specter of environmental security increasingly haunts not only borders and policing practices (Jones 2016) but also development projects themselves. ${ }^{4}$ Such an interrogation is pressing in light of the emergence of climate security as a key term in global governance. Climate security, broadly, frames a range of concerns about global warming through the lens of sovereignty, security, and borders. While it is a term used in different ways by different actors, broadly it maps fears about the impact of massive environmental displacement and migration onto existential concerns about the future of borders and sovereignty. ${ }^{5}$ Scholarship on climate refugees has highlighted the ways in which the imagining of a world inundated by the environmentally displaced increasingly drives security agendas in the United States and Europe (Hartmann 2010; Parenti 2011; Bettini 2013). As I suggest here, this emergent concern with climate security should not be read in isolation from development and humanitarian intervention. Indeed, climate migration constitutes the latest object of the so-called development-security nexus - the postCold War collapse of distinctions between security, development, and humani- 
tarian measures. ${ }^{6}$ Ethnographically engaging these assemblages that meld climate, security, and development proves critical in a political environment in which security offers a primary lens through which policy makers evaluate responses to and planning for climate change (Samimian-Darash and Stalcup 2016).

The blurring of the line- historically fuzzy to begin with (Cullather 2010) between security and development is particularly evident in a range of new projects emerging in places understood as the front lines of climate change. The Bangladesh delta region is one such place. The country at large is regularly framed as one of the canaries in the proverbial climate coal mine. But much of the national and global anxiety about the country's climate future is directed specifically at the delta region - a borderland zone with a population of 20 million people that many believe may become uninhabitable within the next century, triggering massive climate migration both within and across the country's borders. The southwest delta region of Bangladesh constitutes an apt example of what Mark Duffield (2007, 126) calls "the global borderland": unruly spaces imagined as on the doorstep of donor states. Much new programming deployed in the borderland zone by international NGOs and donor organizations such as the United States Agency for International Development (USAID) focuses on the need to manage climate change's displacing outcomes.

The killa, and other conceptually similar projects that I will discuss later in this essay, are not representative of all interventions afoot in the Bengal delta. ${ }^{7}$ Yet their focus on a disaster preparedness that will allow people to remain emplaced in the climatological landscape illuminates a securitized vision of climate change. This genre of climate programming evolves portable humanitarian technologies that, in Peter Redfield's $(2012,178)$ words, "anticipate state [and ecological] failure and seek to provide a small scale, self-contained alternative" (see also Cross 2013). In other words, emplacement programming mitigates against the figure of the climate refugee by offering technologies designed to keep people in (their) place. Many of these humanitarian technologies intervene at a household scale. They frame the future of climatological borderlands not as comprising communities holding out against the ravages of climate change, but as individual families surviving in self-contained spaces characterized by isolation and fortified against the chaos unfolding around them. Yet these projects are tinged with a seeming pessimism about their own possibilities of success. While they present themselves as awaiting an immanent scaling up in climate hot spots around the globe, their designs simultaneously speak to the limits and futility of these experimental interventions. As I will show, they often serve more as representa- 
tional technologies for an anxious Western world, claiming that the development industry is forging solutions to impending climate crisis. In this regard, they are spectacles for audiences elsewhere.

This article casts ethnographic light on this new heterodystopian genre of climate intervention. I start by framing the concept of heterodystopia against Foucault's notion of heterotopia. I then explore the terrain and logic of heterodystopia by tracing the emergence of Bangladesh, and especially the southwestern borderlands, as ground zero for climate change and as a laboratory for so-called resilient development. I subsequently return to the borderland landscape of Munshiganj to explore how heterodystopias emerge in practice. In doing so, I examine the architecture, politics, and poetics of specific projects unfolding in the delta borderlands. I return, briefly, to the mattir killa discussed above, but look more specifically at an example of "climate-smart" development. These new interventions, I argue, are shaping and transforming the border milieu of the southwest delta region in unprecedented ways (cf. Martinez 1994). Yet they are not the only ways of managing ecological change. Local populations continue to forge crucial political alternatives to interventions of international donors - alternatives to which we must attend if we wish to think beyond the logic of heterodystopia. I accordingly conclude by briefly exploring grounded, alternative projects carried out by residents of the Bangladesh borderlands themselves.

\section{FRAMING HETERODYSTOPIA}

Over the past decade, much work in anthropology and beyond has explored the ways in which imaginations of the future are complicit in the reshaping of the present. The broad thrust of this work is that an increasing alignment of planning with security concerns has ushered in a paradigm of anticipatory governance (Adams, Murphy, and Clarke 2009; Anderson 2010; Adey and Anderson 2011). This paradigm is marked by a transition from prevention to preparedness and preemption (Lakoff 2008; Anderson 2010; Massumi 2015). Such a shift signals a transformation in the logics of planning _ one that focuses not on ways to forestall oncoming crises, but rather sees them as inevitable features of the future terrain and, instead, focuses on identifying and addressing vulnerabilities in response capacity. Work tracing the temporalities of disaster risk reduction, vital systems security, and biosecurity shows that anticipation constitutes a powerful logic for remaking the world (Choi 2015; Collier and Lakoff 2015; Whitington 2016; Zeiderman 2016). As Brian Massumi (2015, viii) points out, this shift toward preemption and anticipation marks a shift in the ecology of power-an emergence 
of "a new power for bringing into being." In short, anticipation effects a reordering of the social around future threats.

If anticipatory planning marks the zeitgeist of contemporary governmentality, it is far from monolithic. It has multiple genres, situated contexts, and cultural vocabularies in need of ethnographic attention (Lowe 2010; Samimian-Darash 2016). I suggest that we understand what I here call heterodystopias as a specific genre of anticipatory governance: one that frames particular spaces at once as sites of experimental management for future crisis and as representational zones that enact spectacles of containment and securitization. Understanding these projects as heterodystopias provides ways to diagnose not only the seeming oddities of the projects themselves but also the conflicted imaginations of the future embedded in their materiality. The heterodystopias I explore speak in the name of resilience, but they also speak to a broader set of anxieties about the future by taking the delta as a demonstration site for climate development.

I frame my articulation of heterodystopia in direct relation to Foucault's brief yet provocative discussions of heterotopia. In contrast to utopias (sites with no real location), Foucault offers heterotopias as countersites, spaces of enacted utopias. These places ground a utopian vision and reflect that vision, as in a mirror, back onto the spaces beyond their boundaries. ${ }^{8}$ Central to heterotopia is the notion of emplacement - situating or putting in place. Emplacement is a fundamentally relational term: one that allows for articulation across space and place (Johnson 2006). ${ }^{9}$ Heterotopias, for Foucault $(1998,178)$, are emplacements that "have the curious property of being connected to all the other emplacements, but in such a way that they suspend, neutralize, or reverse the set of relations that are designated, reflected, or represented [réflechis] by them.” Their role is either "creating a space of illusion that denounces all real space, all real emplacements within which human life is partitioned off, as being even more illusory. . . . Or, on the contrary, creating a different space, a different real space as perfect, as meticulous, as well-arranged as ours is disorganized, badly arranged, and muddled" (Foucault 1998, 184). The demonstration plot articulates and represents the idealized model of agricultural development. The penal colony enacts the containment of those who stand in the way of a perfected society.

Heterotopia is a notoriously slippery concept. Yet it provides an interesting lens for thinking through development. Historically, development interventions - especially projects such as model villages, demonstration plots, and pilot programs - have been heterotopic: countersites that are enacted utopias evoking other spaces of potential development (or its lack). They constitute slices of time 
(what Foucault awkwardly terms "heterochronia") where the future is manifest in the present and within a specific and highly circumscribed geography. Standing, in principle, in relation to all other spaces of potential development, these sites both act on those who live within them and act to represent the possibilities of utopian perfection, a developed world in which poverty has been eradicated through technocratic management.

Bangladesh has historically been an epicenter of heterotopic development. Often described as the "Wall Street of development" and as "the Aid Lab" (Hossain 2017), the country has been the site of numerous models and reflections of utopian futures meant for propagation in abstract elsewheres - from the Comilla model of village development in the 1960s through the 1980s, to the Grameen model of entrepreneurial self-help through microcredit in the 1980s through the 2000s (Karim 2011). ${ }^{10}$ Yet the rise of climate security as a paradigm of development has significantly shifted the frame. New development interventions like the killa, which emphasize security through emplacement (as opposed to, say, offering development through market integration), work in ways roughly analogous to older heterotopian projects, though toward markedly different and darker ends. They are not spaces framed in relationship to a utopian future. Rather, they are oriented toward a future in which increasing chaos characterizes the problems of management and governance. They are climate heterodystopias: windows onto life in a warming world and, as such, opportunities to manage future crises. These spaces are constituted as temporal discontinuities. In and through them, the Bangladesh borderlands emerge as a sentinel site, a space of "vigilant watchfulness that can aid in preparation for an uncertain, but potentially catastrophic future" (Keck and Lakoff 2013). They offer a space that allows for the testing and demonstration not of solutions to climate chaos, but for the management of its presumably inevitable effects. They thus constitute spaces that facilitate a specific form of anticipatory governmentality — one organized around the deployment of technologies for maintaining life in the imagined multitude of devastated landscapes to come.

\section{MAKING THE CLIMATE BORDERLAND}

To understand how heterodystopias manifest in the delta, we must understand the making of the southwest delta region as a climate borderland. As countless studies have pointed out, Bangladesh - because of both its geography and its history - is likely to be an early victim of global warming. ${ }^{11}$ In part because of this acute vulnerability and in part because of Bangladesh's long history as a front 
door of global development (Feldman 2003; Lewis 2011; Hossain 2017), there has been a massive influx of donor funds into the country in recent years aimed at addressing climate change.

The recasting of Bangladesh as an epicenter of climate change has reached such a level that it has now become the stuff of glossy commercial publications and global accolades. A case in point is a recent coffee-table book published by the COAST Trust with support from Bangladesh's Ministry of Foreign Affairs, titled A Tale from Climate Ground Zero (Shibly and Mehedi 2015). The book celebrates Prime Minister Sheikh Hasina's receipt of the 2015 United Nations Champion of the Earth Award for leadership on global climate policy. It is filled with striking photos depicting not only familiar scenes of climate change-storm-damaged homes with water lapping at the door, eroded river banks, and so on-but also images highlighting village-level adaptive development innovations afoot in the country to combat advancing climatological disaster. The book's preface, an excerpt from Hasina's acceptance speech, states: "As one of the most climatevulnerable countries, Bangladesh is moving with innovative ideas to address complex climatic challenges in a sustainable manner. . . . We are ready to share our modest innovation and experience with others. That is, our contribution to turn 'vulnerability' into 'resilience'” (Shibly and Mehedi 2015, 3).

This transformation, like the award the book celebrates, is far from an exclusively Bangladeshi project. Arguably, the award celebrates Hasina's willingness to allow foreign donors to implement myriad projects and policies to combat climate change in Bangladesh as much as it does innovation on the part of her government. Figured against the realities of these interventions, the book is best read as a celebration of a vast array of national and international development projects remaking the country, reframing its future across scales, and packaging its "contribution" of resilience to a climate-affected world.

While climate change stands to impact much of Bangladesh, the epicenter of climate programming is the southwest. The region is acutely vulnerable to cyclonic activity, sea-level rise, and increased soil salinity. Yet vulnerability is only part of what makes this zone a hot spot of climate-related development. Equally important, though significantly less discussed, is that it is a sensitive borderland region (Cons 2016). The India-Bangladesh border has historically been a source of regional tension: a communally defined line separating a supposed Hindu territory from a supposed Muslim one. ${ }^{12}$ In recent years this borderland has also emerged as a space of considerable global climate anxiety, aptly captured in a New York Times article tellingly titled "Borrowed Time on Disappearing Land" 
(Harris 2014). The story vividly ties the effects of fossil-fuel consumption to rising sea levels and their impending effects on low-lying coastal areas in southwestern Bangladesh. While the story itself lays out a familiar narrative- the imminent erasure of many of the islands that make up Bangladesh's delta region - what is perhaps most striking is an accompanying video, which offers a satellite-view model of what will happen to the delta in the face of a thirteen-foot sea-level rise. The video unfolds over a long minute in which viewers watch much of the delta disappear under water. The final text reads, "Scientists expect the rising waters in Bangladesh to displace eighteen million people in the next forty years." The video offers a dramatic illustration of what drives climate anxiety in and about Bangladesh: the prospect of massive displacement, a specter that manifests most readily in the figure of the climate refugee.

This anxiety drives much of the contemporary transformation of Bangladesh into a sentinel site of climate change and a global climate security concern. As Frédéric Keck and Andrew Lakoff (2013) argue:

The figure of the sentinel is bound up with both the problem of perception and the question of whether the detection of danger can successfully ward off a coming crisis. In the contemporary context of ecological anxiety, the sentinel has taken on an expanded meaning: it has come to describe living beings or technical devices [and, one might add, particular sites] that provide the first signs of an impending catastrophe.

This double bind of perception and possible response drives anxiety over climate change in Bangladesh. Moreover, it overtly and covertly informs much contemporary discussion about the border within India, where migration has long served as a rallying point for the Hindu right (Ramachandran 1999; Sur 2014). The realities and imaginations of cross-border displacement contribute to a mode of politics that Sanjay Chaturvedi and Timothy Doyle (2015) aptly characterize as "climate terror." The imagination of an inundated Bangladesh is regularly coupled with a framing of India, and particularly the states adjacent to Bangladesh, as drowned in a tidal wave of (Muslim) migrants (see Thankuria 2015).

The specter of climate refugees weighs heavily on other imaginations as well. In 2015, I spoke with a senior British development professional working for a large international aid organization and about to complete a multiyear posting in Bangladesh on the politics of climate-related development. He explained this politics to me as a fear of global migration: "This is where the UK redlines. We can't handle 165 million Bangladeshis showing up on the UK's shores." It is this 
fear that animates the reframing of the India-Bangladesh border as a marker of what Joseph Masco (2010) calls "planetary threat." Framed as a "global 'national security' issue" (Friedman 2009), this border is increasingly positioned as a test case for climate security and for understanding the future of migration in a warming world. This vision of the border can be seen in its increasing presence in climate-change war games and strategy scenarios in the United States and Europe. For example, the "Clout and Climate Change" war game, staged by the Center for New American Security in 2008, imagined an Indian border beset by a climatemigration catastrophe following a fictional 2013 cyclonic event in the Bay of Bengal. ${ }^{13}$ In doing so, it tested the organizational capacity of the international community to respond to (rather than prevent) climatological disasters by stemming migration before it compromises regional and global stability (Lakoff 2008; Anderson 2010). Similar exercises at the U.S. National Defense University and the Naval War College have tested the outcomes of massive population displacement and the ability of the U.S. Navy to respond to major climatological disasters in Bangladesh (Funk 2014). In short, the stakes of change in the region are high, and not just for residents.

\section{RESILIENCE, OR, THE CULTURAL LOGIC OF CLIMATE HETERODYSTOPIA}

What might this transformation from vulnerability to resilience mean for Bangladesh and for climate-related development within it? Resilience is a concept that has taken the development industry by storm over the past decade. Genealogically, the concept of resilience borrows from both late-Hayekian theories about the market and Crawford Holling's complex systems theory, developed in the 1970s (Walker and Cooper 2011). Its contemporary uses in development and its relationship to terms such as adaptation can often seem flexible and slippery. It signals both the limits of traditional development planning and a revised attention to what will be expected of the subjects of development in the future. For example, the same development professional concerned about the redlining of the United Kingdom under the weight of climate migration who was introduced in the previous section went on to describe climate-related development as a project of mitigating migration through resilience. He further explained the logic of resilience as a way of thinking strategically about probability and risk. Resilience provided a sophisticated form of systems thinking to potentially mitigate against the future of climate change. It did this by offering a more complex engagement with risk and investment than other (older) models of climate programming such 
as adaptation or disaster risk reduction. Potential solutions to this problem of migration included more robust disaster planning and infrastructural development. Yet resilience thinking also called many of these solutions into question. To demonstrate his point, the professional, as we spoke, spun out a long series of risks and challenges to development in the southwest, such as groundwater and soil salinization, sea-level rise, the waterlogging of islands in the delta, and more. He emphasized the ways in which these challenges multiplied and complicated each other, exposing the successive limitations of each new intervention that a resilience-oriented perspective exposed.

As we spoke, each successive risk related to climate change in the delta region seemed to cancel out the possible long-range efficacy of existing and possible interventions and to call into question the continued investment of capital in durable large-scale projects. As he conceded ultimately: "The problem is that in a decade, that area [the southwest] is going to be unthinkable. The likelihood is that the region is only going to get tougher. . . . We're doing a managed retreat from the coastline." It is important to note that not all organizations working in the area necessarily share this sentiment. As a consultant for the World Bank told me over coffee in Dhaka, "neither we nor the Government of Bangladesh are ready to give up on the southwest." But it does highlight the emergence of a logic in programming that is designed to help populations fend for themselves in lieu of other development solutions. Resilience thus shifts the primary burden of preparedness from states to individuals. In other words, if the investment in durable infrastructure to address climate transformations is increasingly conceived as either cost-ineffective or impossible, what remains are strategies to help residents of climate hot spots be resilient - that is, to manage the crisis on their own.

Resilient development, as critics have increasingly pointed out, substitutes a vision of development as aspiration and achievement for one reduced to coping. It is a form of governance aimed not at solving or preventing dangers to security, but rather at increasing capacities to weather a range of impending storms (Evans and Reid 2014; Watts 2014). Read as such, resilience appears as the latest manifestation of human security, a project, as Mark Duffield (2007) argues, of globalizing and containment. Resilient development globalizes security concerns such that remote spaces like Munshiganj are brought into relation with the security concerns of the global North. And it attempts to contain such spaces by providing the tools to ensure that surplus populations can remain in place, as opposed to migrating across sensitive borders demarcating "effective" from "ineffective" states (Duffield 2007, 111). ${ }^{14}$ In other words, resilience programming forms a bulwark 
against the chaos of climate migration: a set of mechanisms to territorialize spaces and their residents - keeping them firmly emplaced. As such, it is also best understood as the logic of heterodystopian development.

\section{LANDSCAPES AND ARCHITECTURES OF HETERODYSTOPIA}

The agrarian landscape of Munshiganj is variously divided between agricultural fields (largely used for growing the aman, or monsoon, rice harvest), and brackish-water shrimp aquaculture ponds, or ghers. The region is increasingly freshwater-scarce and its soil increasingly saline due to a combination of factors, including saltwater intrusion, aquifer depletion, and the proliferation of brackish water aquaculture. ${ }^{15}$ Because of a lack of available fresh water for irrigation, most of Munshiganj's farmers grow only a single rice crop, as opposed to the two to three harvests common in many parts of Bangladesh. The region was severely affected by Aila, which washed away large sections of the protective embankments in the adjacent island of Gabura. This exposed the island's residents and agricultural land to a twice-daily tidal inundation of salt water. ${ }^{16}$ Immediately following Aila, the island became a humanitarian relief zone. Numerous buildings still bear signs marking them as constructed under the auspices of relief efforts by organizations such as Oxfam and CARE. The devastation of Aila set the stage for the region's transformation to a site for climate programming. Indeed, since 2009, the region has been reconceived as a place where climate change has, effectively, already happened. Consequently, Munshiganj is awash in projects that claim to instill resilience in the lives of residents. Figure 2 gives some sense of the density of new climate projects in the area. It is a photo of a single street corner in Munshiganj town. Each signboard in the photo points the way to the office of a different NGO working in the region, each with their own suite of climateadaptation and resilience programs.

Beyond Munshiganj town, ubiquitous signboards mark a dense scattering of climate-related development interventions. These signs simultaneously call out the limited nature of many of these projects: demonstration plots in people's backyards, limited training programs that seek to educate farmers on new ways of growing vegetables, single-family rainwater collection wells, and the like. One day, while passing through a hamlet to the east of Munshiganj town, my colleague and I stopped to ask a group of farmers about development programs in their village. One retrieved a sign marking a USAID vegetable test plot from a disused corner of his yard, and sardonically held it out for display. As his gesture sug- 


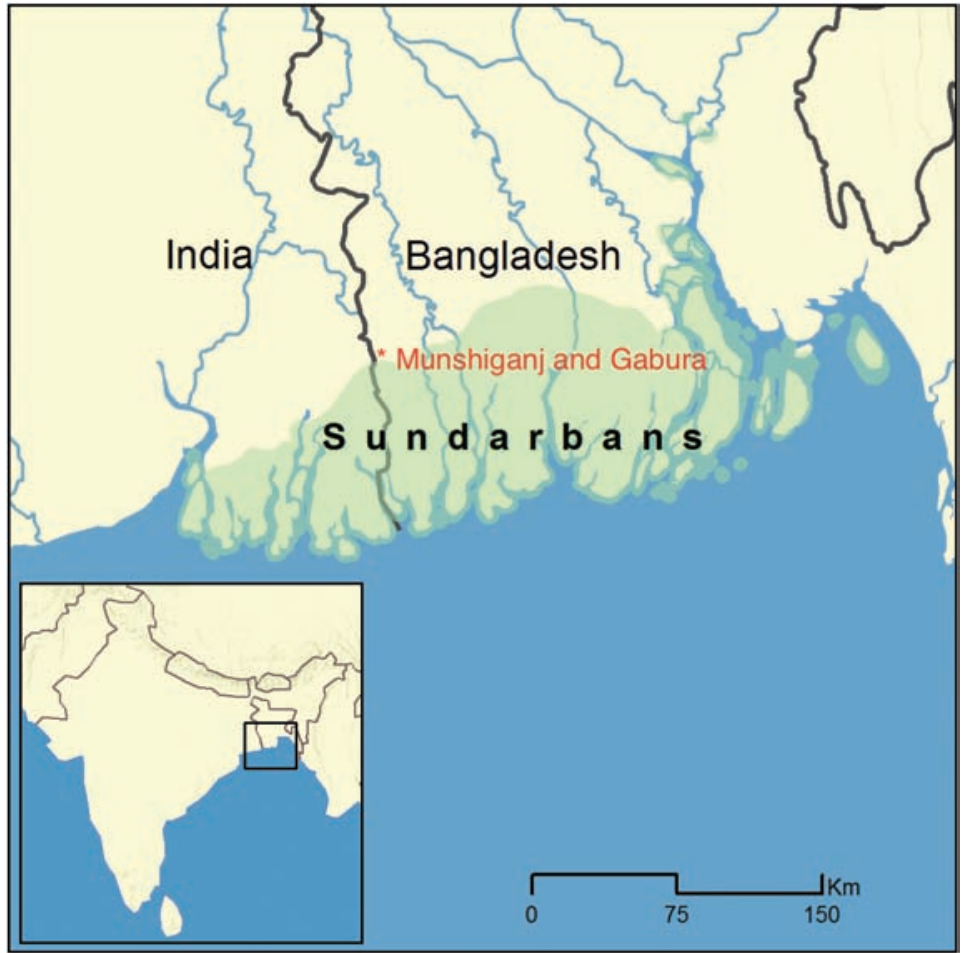

Figure 1. Map of Munshiganj, Gabura, and the Sundarbans. Map made by Amanda Henley.

gested, signboards are often cast away not when projects have run their course, but simply when their beneficiaries lose interest in the interventions.

Residents of Munshiganj are often alternatively bemused and frustrated by these interventions. For example, many of those who lived near the killa discussed at the outset of this essay found the project more an exasperating waste than a portent of the future. Many wondered why the mound had been constructed instead of a concrete cyclone shelter that could provide robust protection from the periodic storms that blow in off the Bay of Bengal. Others complained that, because the killa was constructed on private property (owned by a farmer who was a politically powerful member of local government), it was, essentially, single-use in nature. One person angrily told me: "As much as I can see, there is not one inch of profit in it. Unnecessary place, unnecessary project!” A group of laborers we spoke with in a nearby tea stall had a wryer take on the project's uses. As one told us, chuckling into his tea, "well, when the winds come, we will just huddle close together. That way we won't get blown off.” If these comments 


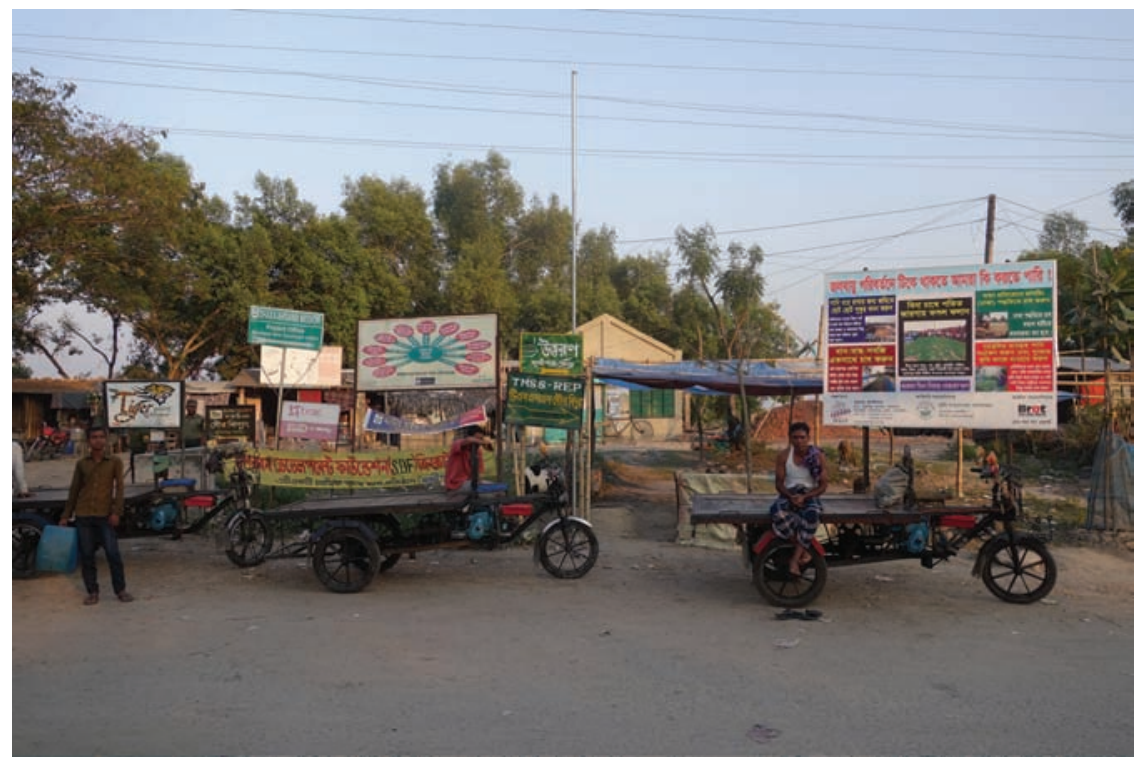

Figure 2. NGO signboards on a street corner in Munshiganj Town. Photo by Jason Cons.

reflected a darkly humorous take on climate-change interventions, they also highlighted a clear understanding of what is at stake in such projects. Residents of the region are intimately aware of the impending impact of climate change and the ways it stands to affect livelihoods and lives.

In the concluding paragraph of his discussion of heterotopias, Foucault (1998, 184-85) notes that a ship is the heterotopia par excellence: "The ship is a piece of floating space, a placeless place, that lives by its own devices, that is self-enclosed and, at the same time, delivered over the boundless expanse of the ocean." In contrast, an island might figure as a heterodystopia par excellence - a landscape beset by seas, but firmly fixed in place. ${ }^{17}$ As the killa suggests, the vision of the future in resilient development projects in Munshiganj is an imagination of family units isolated from, yet fortified against, unfolding catastrophe around them.

Yet what does this vision of the future do, and to what end? To answer these questions, it is instructive to explore one of the most recognizable projects in the Munshiganj region — a "climate-smart integrated house," constructed in Gabura and meant to help residents survive the chaos of climate change in place. We had heard about this house from a WorldFish project manager in Dhaka who breathlessly described its architecture and its many adaptive technologies. WorldFish is an international research organization and member of the United 
Nations Consultative Group for International Agricultural Research. The organization has a large presence in Bangladesh, especially in the southwest. ${ }^{18}$ The house itself was a one-off demonstration project constructed at a material cost of $\$ 6,000{ }^{19}$ The project was famous, or perhaps infamous, in Munshiganj, and known locally simply as either the Pani (water) House or as dui tolla (two-story), a reference to the fact that it was the only home on the island with two stories.

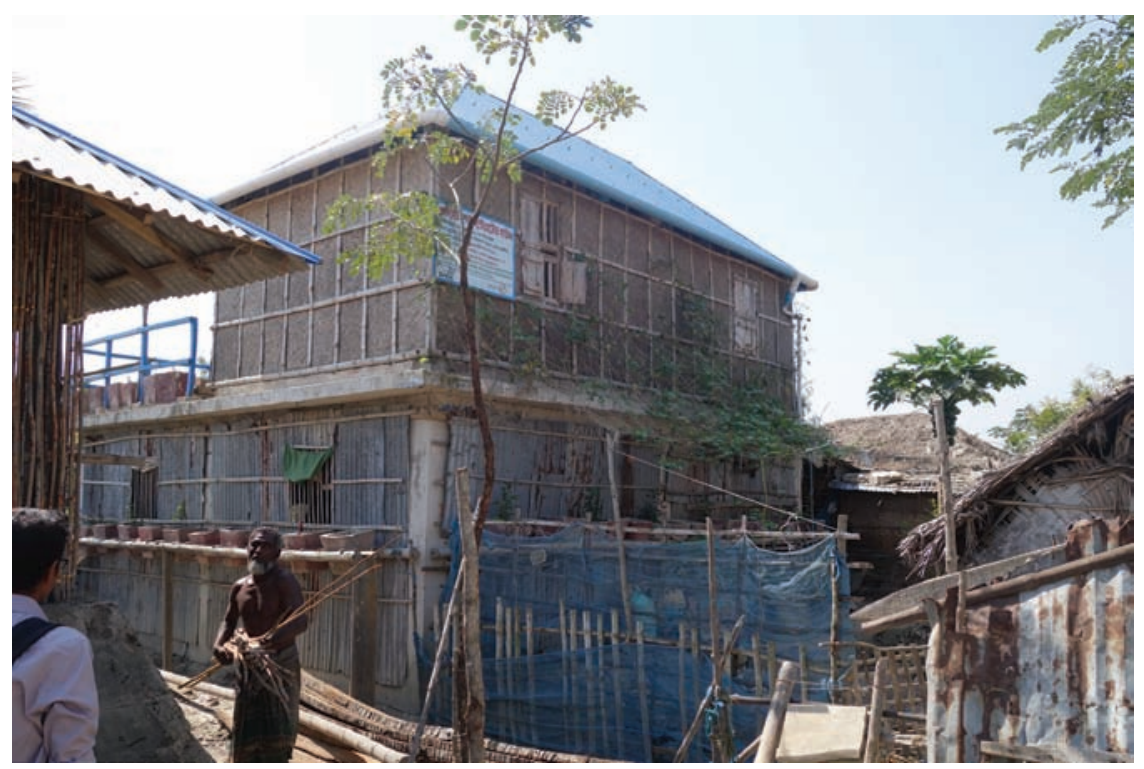

Figure 3. Pani House, Gabura. Photo by Jason Cons.

The house sat in a village primarily inhabited by smallholder farmers and landless laborers. It housed a single family chosen through their industrious participation in NGO support groups following Aila. The house contained a showcase of development technology: a covered well for irrigation, storage tanks for drinking water, an indoor fish pond, complex drip-irrigation systems, and much more. When we first visited, these technologies were demonstrated, one by one, as other residents of the village gathered around to watch.

WorldFish claims the Pani House as a model of resilience. ${ }^{20}$ As the organization's project report on the house states: "Changes in climate will affect local weather patterns and impact many people's livelihoods. The climate-smart house provides protection against cyclones and flooding and supports efficient use of water and energy. Many features of the house are aimed at increasing food production and helping families become more self-sufficient and better able to cope 
with extreme weather events" (Hossain, Nurun Nabi, and Kaminski 2015, 3). In other words, the Pani House was conceived as a comprehensive humanitarian technology of emplacement, allowing residents to survive and thrive in a coming ecology that will be both disaster-prone and resource-scarce. It was a project that addressed broad concerns about climate security and migration by providing tools to help residents not migrate. Equally important, the project was a pilot. The report suggests that "communities should work with government representatives to encourage the building of climate-smart housing in vulnerable areas" (Hossain, Nurun Nabi, and Kaminski 2015, 7). The communities in question seem unlikely to be those in the delta, where it is difficult to imagine an intervention that costs $\$ 6,000$ per household adopted at scale, because such a project would quickly run to billions of dollars in cost. Rather, the Pani House was conceived as an abstract and portable technology, ready, though perhaps unlikely, to be deployed in other areas of climate disaster.

In practice, the Pani House's various technologies were fraying at the edges. For example, the complicated drip-irrigation systems that were supposed to allow residents to grow household plants in window boxes isolated from saline soil and raised above flood levels relied on plastic drip spigots. Most of these spigots had broken, and were not repairable with materials available in local markets. The stairs to the second story of the house were constructed out of iron, making them rapidly rust in the saline environment. Indeed, as Mehru and Habibur, the residents of the house, told me, a number of problems had emerged with the house's design since its construction. The pair had a series of grounded suggestions for future iterations of the project, such as extending the roof overhang for the house, so that rain was less likely to blow in during the monsoon season. I asked them if WorldFish had collected any of this feedback from them. They told me that they had not had any contact with the designers since the house was built. As Mehru put it: "They have given it to us, but we cannot tell them that we are facing these problems."

The design, architecture, and construction of the house were, I suggest, heterodystopian. They evinced planning not designed specifically for the region, but rather for an abstractly conceived space of climate crisis - one that may be in Bangladesh but could just as well be anywhere. This yielded a range of minor failures of design and planning, such as irreplaceable plastic spigots and iron stairs. Yet more revealing of the heterodystopian vision articulated by this and similar projects were the social implications of the house itself. Foucault $(1998,183)$ describes a heterotopia in which "everybody can enter . . . [but] by the very fact 
of entering, one is excluded." The Pani House proved similar. Anyone, including other residents of the village in which it was situated, could enter to marvel at the technologies of resilient development on display there. Yet none of these technologies were things that the village at large was meant to benefit from. The house was built and designed explicitly for a single family situated within, but removed from, the rest of the community.

I asked one of the house's designers about this and she told me that there were initial plans to make it a community resource. But there were two challenges. First, WorldFish wanted the house to serve as a proof of concept that they could test and collect feedback on (something that they, apparently, have not done). "The second challenge," she continued, "was that we were worried that something that belongs to everyone belongs to no one when it comes to work to provide, and that it creates conflicts when it comes to harvesting benefits." This "tragedy of the commons" vision of development brushes against the many histories of collective organizing by landless and smallholder groups throughout Bengal (e.g., Hashmi 1992). But, like the killa discussed at this essay's outset, it also articulates an imagination of a climate-affected future necessarily composed of individual families surviving on figurative, and perhaps literal, islands, isolated and protected from the unfolding chaos around them. An island unto itself, the heterodystopia of the Pani House enacted the dystopia to come.

\section{THE POLITICS AND POETICS OF HETERODYSTOPIA}

That the Pani House was constructed as a general solution, as opposed to one that addresses the specific condition on the ground, does not in and of itself appear surprising. The notions of piloting and modeling have long been central to development (Cullather 2010). Yet the Pani House raised questions about whether the model was, in fact, meant to be (materially) replicated. Like many other interventions in the Munshiganj region, the Pani House appeared to be a project that privileged the act of modeling over the process of learning from and scaling up new development technologies. This permanent provisional condition hints at other possible meanings and purposes of climate heterodystopias. To understand these, it is necessary to attend to the representational dynamics of these interventions as much as to their impact on beneficiaries.

Development is a profoundly visual language. The point of pilot and model projects is that they demonstrate an efficacy of interventions in a particular location that stands in for a multiplicity of other potential locations. These projects - model villages, demonstration plots, and so on - dramatize the distinction 


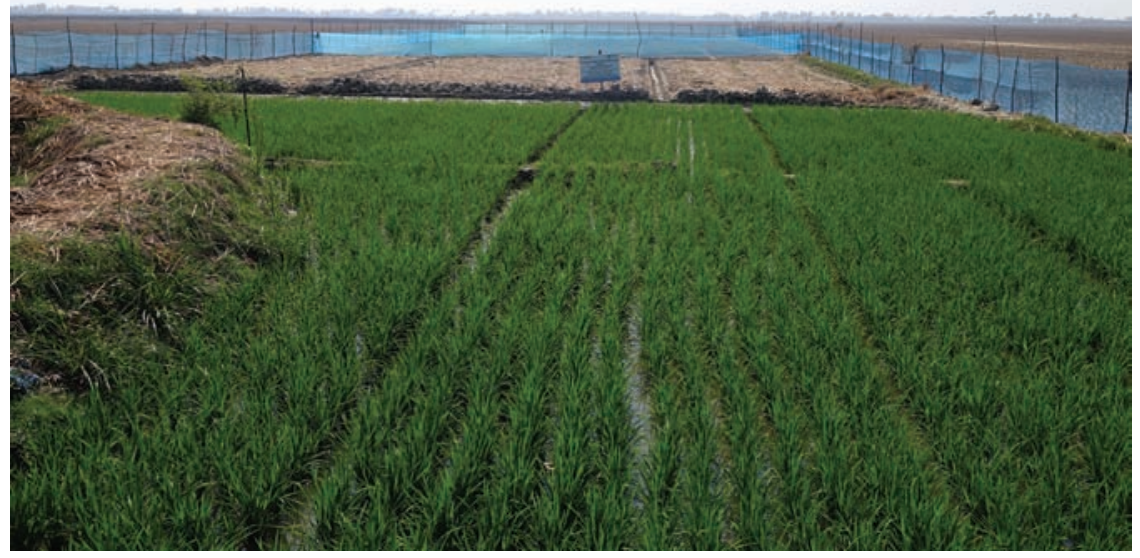

Figure 4. Backyard of the Pani House. Photo by Jason Cons.

between the space of the project and the undeveloped space outside of it. As Nick Cullather $(2004,228)$ writes of Green Revolution technology, "where the dark green rice stopped, that was the edge of the modern." In Munshiganj, the clustering of projects in a single space further heightened these visual distinctions. In a pattern replicated in many projects throughout the region, the Pani House accumulated other development projects within its perimeter. The Pani House's backyard, for example, housed an International Union for the Conservation of Nature (IUCN) test patch for climate-smart watermelon production, as well as a USAID irrigated rice plot. These fields were neatly cordoned off by a blue fishnetting fence that defined the property boundary. The fence marked a stark contrast between the Pani House and the unirrigated, dry, and dusty aman rice fields beyond - the agricultural fields farmed by the other residents of the villages. The message in this contrast proved hard to miss. Unlike older visualizations of development, which dramatized distinctions between modernity and tradition, the boundary here marked a division between impending chaos and its potential management. Inside the project boundaries, resilient development flourished. Outside and surrounding it lurked the nonresilient future.

The accumulation of projects within the Pani House served a dual purpose. The first, and most obvious, was that the presence of one project increased the likelihood of success of the others. The USAID rice plot, for example, was being 


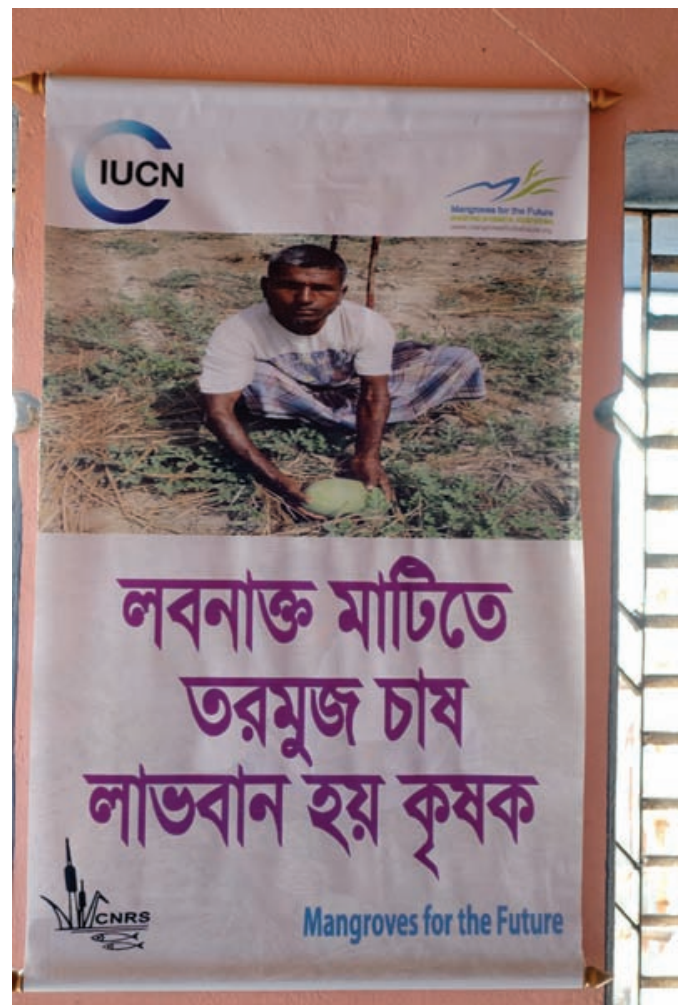

Figure 5. IUCN poster promoting saline-tolerant watermelon production. Photo by Jason Cons.

irrigated by the Pani House's private water supply. But more importantly, this accumulation of projects made the Pani House photogenic. Indeed, the house and its residents appeared in press material for other development organizations working in the region. For example, IUCN designed a poster showing their test plots in the Pani House's backyard and Habibur, one of its residents, by way of promoting saline-tolerant watermelon production (see Figure 5). The contrast between the climate-smart household and other households in the village was dramatic, but also at once beside and precisely the point. The community and the house's residents were not the primary audience for the intervention. Indeed, as my colleague and I were told by a WorldFish project manager in Dhaka, the Pani House was meant more "for the website" than "for the people."

But whether meant as a real project or as a kind of climate set piece, the Pani House also revealed the logics of heterodystopia. The Pani House articulated climate futures in which single families would have to go it alone. The notion of 
a community - however defined as a potential actor in this climate-affected future - was not part of this vision. Moreover, the question posed by projects such as the Pani House was not whether such a vision of the future-climate wasteland with individual resilient families hanging on by their development-enhanced teeth - was a just vision or an acceptable one. Rather, it was simply whether this articulation of resilience proved workable, scalable, and capable of capturing donor imaginations. These interventions emerge as articulations between not just, or even primarily, development practitioners and their beneficiaries, but between development organizations and a global population increasingly concerned about the impending security crisis of global warming. The message in the spectacular image was clear: technological solutions to instill resilience in the face of ecological change are possible and feasible. Moreover, they are already in the works, emplacing life on the front lines of a warming world.

If climate heterodystopias like the Pani House only questionably achieve their stated goals, they are, nevertheless, quite successful at producing aesthetic messages. They are spectacular: spaces of juxtaposition that rely on appearances and images as techniques of power (Debord 1995; Foucault 1998). They constitute not only ways to acclimatize populations to particular logics of life in the Anthropocene but also forms of communication between powerful development organizations and their audiences (Yeh 2013). Seen through this frame, residents of Munshiganj are not just the targets of intervention but also the means of production of spectacles of climate resilience - the vehicles through which a set of technical interventions are demonstrated as efficacious in producing a set of resilience-like effects (Dunn 2012). In other words: while projects in Munshiganj framed the area as a space of climate crisis, they simultaneously offered a technooptimistic claim to donors and concerned individuals elsewhere that development interventions can manage anthropogenic crisis at the margins of global empire.

\section{BEYOND HETERODYSTOPIA}

The Pani House provided a particularly vivid articulation of the intertwined logics of resilience and spectacle in climate borderlands in the contemporary moment. Yet many others like it dotted Munshiganj’s landscape. These ranged from vertical agriculture technologies (projects of replacing household agricultural production in fields with vertical tubes for isolating household vegetable growth from saline soil) to other test houses that, like the Pani House, had received multiple development interventions from multiple development agencies to promote resilient living in the face of climate change. Many homes that had accu- 
mulated donor interventions also were situated on the most productive and least saline soil. In other words, they were homes with the least immediate need of such technology but the most likelihood of visibly demonstrating its value.

Insofar as these heterodystopian interventions reflect a grim vision of a climate-affected future, they not only foreclose a range of possible ways of conceiving development within the region but also contribute to producing the southwest delta as a climatological borderland with an eminently translocal future of disaster. Reading these projects as heterodystopias provides a way to diagnose the specific securitized imaginations of the future that are currently being grafted onto places of uncertain ecological change. Peter Johnson (2006, 87) writes: "With different degrees of relational intensity, heterotopias glitter and clash in their incongruous variety, illuminating passages for our imagination." So too, perhaps, heterodystopias. But precisely because such heterodystopias as the Pani House are manifestations and representations of future containment superimposed on spaces of lived agrarian production, it is critical to ask what other possible futures are masked in dystopian enactment. By way of conclusion, then, I wish to briefly juxtapose these interventions with other projects offering different, more grounded visions of adaptation, resilience, and community.

Of these there are many. They are primarily based on cultivating resources that farmers in Munshiganj see as critical to navigating life in the midst of ecological change. They tend to focus not on disastrous futures but on grounded strategies to improve short-run agricultural productivity. One farmers' collective, for example, is working in collaboration with an organization called the Bangladesh Resource Center for Indigenous Knowledge (BARCIK) to establish local seed banks collecting indigenous seed varietals that are, at least to an extent, saline-tolerant. ${ }^{21}$ They are currently interspersing these indigenous varietals with hybrid varietals as a hedge against uncertain agricultural conditions. Beyond seeds, these collectives are also beginning to articulate their own visions of what technologies they need to develop this more livelihood-oriented approach to resilience (Tanner et al. 2015). Specifically, farmers' groups in Munshiganj argue that they need canals to collect fresh rainwater for crop irrigation. One collective successfully petitioned the local government for a work project to rebuild freshwater canals that had been wiped out during Aila. Combined with several years of good rainfall, members of the collective told me in 2016, the project has seen them experiencing above-average rice yields. They further argue that the canal will help them more easily weather seasons with unpredictable rainfall, a projected effect of climate change in the region. In short, residents of Munshiganj are employing 
collective action in attempts to materialize an agrarian future in which agriculture might transform the island's environment and provide more employment and stability for its residents - especially smallholder farmers and landless laborers.

These projects deserve more attention than I have space to provide here. Whether they will work in the long run is, of course, an open question. They are as experimental, in some ways, as the Pani House. However, the alternative visions and different temporalities embodied in these farmers' initiatives to reclaim land in Munshiganj have an important role to play in contesting heterodystopian visions. These projects enact engagements with a resilience that is situated in the everyday politics of land and livelihoods in Munshiganj, rather than framed against global imaginations of a securitized and crisis-ridden climate future. They are not meant to reflect or engage an abstract infinity of spaces, but are rather eminently local, prosaic, and practical. Moreover, they are not predicated on exclusionary visions, such as the Pani House, but rather on inclusion, communal investment, and participation. These visions of an agrarian livelihood might provide both a form for apprehending and a means of giving shape to futures that heterodystopian development projects categorically reject (Zee 2017). Ironically, in providing grounds for people to continue pursuing agriculture in what others imagine as a climate wasteland, they may prove more successful in achieving the emplacing goals of resilient development. They thus hint at an optimistic vision of a future where resilience might be defined not only by remote spatial imaginaries and distant audiences alone but also by peasants working in communitarian ways to collectively secure access to water, land, seed, and life.

The Bangladesh borderlands are spaces within which we can begin to see the confused projections of climate futures (particularly those involving borders and migration) embodied in present-day development interventions. The emplacing technologies in Munshiganj imagine a world in which populations survive as atomized families, deploying various humanitarian technologies to help them remain fixed in a climate-ravaged landscape. Yet the recursive constitution of these interventions as spectacles suggests that we should understand them not only as pilot projects of resilience. They also speak in an idiom framed by a broader failure to address climate change at a planetary scale, a set of anxieties about climate induced migration, and a need to project technological mastery of emerging security concerns in climatological borderlands. Exploring these projects as heterodystopias reveals ways in which security and development are jointly remaking a climate-affected world in the present. 
Reading these interventions alongside other imaginations of the future offers a crucial contrast. The interventions launched by farmers' collectives in Munshiganj are grounded responses to ecological change that cast populations neither as hapless victims of, nor stoic resistors to, climate injustice (Castree et al. 2014; Hall and Sanders 2015). Instead, they highlight a parallel terrain of experimentation based on radically different, and strikingly prosaic, understandings of ecological change. Climatological borderlands are thus opportune spaces to observe what Arjun Appadurai $(2013$, 1) has recently called "the politics of possibilityagainst the politics of probability" in the era of climate change. They suggest a need to think resilience beyond narrowly securitized visions of emplacement and to rethink climate change from the standpoint of those navigating life in its midst.

\begin{abstract}
This essay interrogates an emergent genre of development projects that seek to instill resilience in populations likely to be severely impacted by climate change. These new projects venture a dark vision of life in a warming world-one where portable technologies become necessary for managing a future of climate chaos. I propose, following Michel Foucault, understanding these projects as heterodystopias: spaces managed as and in anticipation of a world of dystopian climate crisis that are at once stages for future interventions and present-day spectacles of climate security. My exploration of these projects is situated in the borderlands of Bangladesh, a space increasingly imagined as a ground zero of climate change. The projects discussed frame the borderlands as a site that reflects forward onto a multiplicity of (other) dystopian spaces to come. Their often puzzling architecture reveals a grim imagining of the future: one in which atomized resilient families remain rooted in place, facing climate chaos alone, assisted by development technology. In this way, these projects seek to mitigate against global anxiety about climate displacement by emplacing people - preventing them from migrating across borders increasingly imagined as the front lines of climate security. Yet at the same time, these projects speak a visual language that suggests they are as much about representing success at managing climate crisis to an audience elsewhere as they are to successfully stemming climate migration in a particular place. Heterodystopia provides an analytic for diagnosing the specific visions of time and space embedded in securitized framings of the future. In doing so, however, it also points toward counterimaginations and possibilities for life in the midst of ecological change. I thus conclude by contrasting climate heterodystopias with other projects that Bangladeshi peasants living in the borderlands are carrying out: projects that offer different ways of imagining the environment and life in the borderlands of Bangladesh. [borders; climate change; development; resilience; security; Bangladesh; South Asia]
\end{abstract}




\section{NOTES}

Acknowledgments This essay has been immeasurably improved through dialogue with and feedback from Elizabeth Dunn, Gökçe Günel, Courtney Handman, Erin Lentz, Duncan McDuie-Ra, Townsend Middleton, Nayanika Mathur, Paula Newberg, Kasia Paprocki, Raj Patel, James Slotta, four anonymous reviewers, and the editorial team at Cultural Anthropology, especially James Faubion. Kasia Paprocki shared in an early portion of this fieldwork and generously gave of both her time and contacts. An earlier version of this essay was workshopped at the Skagen School 2 meeting in 2016, where helpful comments were offered by Erin Collins, Michael Eilenberg, Reece Jones, Christian Lentz, Christian Lund, Jonathan Padwe, Nancy Peluso, and especially Mike Dwyer. Support for this research was provided by the University of Texas at Austin and by a National Science Foundation grant (Award no. 1560531). All errors are my own.

1. In this essay, I discuss Munshiganj and the adjacent island of Gabura. For simplicity's sake, where possible, I refer to these linked spaces simply as "Munshiganj."

2. An initial stage of fieldwork for this project was conducted in collaboration with Kasia Paprocki.

3. Typically, demonstration projects in Munshiganj are funded by large NGOs such as Christian Aid and implemented by local NGOs such as Shushilon, who work as subcontractors. Often these subcontracting NGOs are staffed primarily by Bangladeshi nationals, sometimes hailing from the regions where the development project is being carried out. As Lamia Karim's (2011) work shows, such local employees are anything but simple ciphers of ideas and objectives from above. This holds equally true in Munshiganj. However, in extended conversations with employees of local NGOs, I heard more discussion about development oriented toward future projects and contracts, rather than toward engagements with existing (already built) ones.

4. A more central focus of scholarship on development and climate change has been conservation schemes such as REDD+ (Mathews 2014; McElwee 2015), as well as the entanglements of expertise and adaptation (Orlove 2009; Vaughn 2017).

5. The policy debate over the security implications of climate and migration has grown markedly over the past five years. For a comprehensive discussion of U.S. concerns, see Werrell and Femia 2017.

6. On the convergence of development and security, see Duffield 2010, Stepputat 2012, Gupta 2015, and O’Neill 2015.

7. Indeed, as Paprocki (2018) suggests, much programming in the delta focuses on managing outmigration from rural areas and into urban ones.

8. For critical readings of heterotopia, see Soja 1996, Hetherington 1997, and Dehaene and De Cauter 2008.

9. My understanding of emplacement in terms of "keeping in place" in this essay is consistent with, but does not encompass Foucault's broader use of the term. I thank James Faubion for pointing this out.

10. Faubion (2008, 35) notes that Foucault's notion of heterotopia and Victor Turner's concepts of liminality and communitas emerge out the same "intellectual ecology of the turbulent drift of the 1960s and 1970s," an observation that might be extended to engage the imaginings of development that dominate programming in this period.

11. See Paprocki 2015 for an analysis of the historical amnesias that attend climate change in Bangladesh.

12. See van Schendel 2005 for the definitive history of this border.

13. For an analysis of the implications of this particular climate war game, see Marzec 2015.

14. Duffield's use of the language of "effective" and "ineffective" states is intended as a critique of the normative framing of human security discourse. Yet it also strikingly captures the international portrayal of the India-Bangladesh border.

15. The ghers are outcomes of a three-decade-long boom in export-oriented shrimp aquaculture that continues to structure the politics of land use throughout the southwest (see Islam 2014). Shrimp farming has contributed dramatically to environmental change 
and to agrarian dispossession in the southwest (Paprocki and Cons 2014). For more on the political ecology of shrimp in the region and its links to climate adaptation, see Paprocki and Huq 2018.

16. Following Aila, many were forced to move onto the remaining embankments while the damaged areas were repaired with makeshift earthen mounds. Here, see Roy 2014.

17. As such, climate heterodystopian projects articulate with Peter Sloterdijk's (2009) discussion of the absolute island, a space "which is placed as a completely implanted lifeworld into a milieu inimical to life.” See also Günel 2011.

18. WorldFish is primarily oriented toward fisheries and aquaculture. It plays a key role in discussions of development in Bangladesh today, in part because of the centrality of aquaculture to the country's vision of sustainable development. Yet, as the Pani House demonstrates, it is also involved in broader climate-focused development.

19. Though that house was the only example of this particular design, the genre of the climate-proof house is one favored by multiple development agencies within Bangladesh and beyond.

20. For a discussion of the ways that the house fits into Bangladesh's broader "adaptation regime," see Paprocki 2018.

21. BARCIK, unlike other Bangladeshi NGOs discussed in this essay, is not a subcontracting implementer for larger international organizations. Its programs are developed in dialogue with the communities where it works.

\section{REFERENCES}

Adams, Vincanne, Michelle Murphy, and Adele E. Clarke

2009 “Anticipation: Technoscience, Life, Affect, Temporality." Subjectivity 28, no. 1: 246-65. https://doi.org/10.1057/sub.2009.18.

Adey, Peter, and Ben Anderson

2011 "Event and Anticipation: UK Civil Contingencies and the Space-Times of Disaster." Environment and Planning A 43, no. 12: 2878-99. https://doi.org/ $10.1068 / \mathrm{a} 43576$.

Anderson, Ben

2010 "Preemption, Precaution, Preparedness: Anticipatory Action and Futures Geographies.” Progress in Human Geography 34, no. 6: 777-98. https://doi.org/ $10.1177 / 0309132510362600$.

Appadurai, Arjun

2013 The Future as Cultural Fact: Essays on the Global Condition. New York: Verso.

Bettini, Giovanni

2013 "Climate Barbarians at the Gate? A Critique of Apocalyptic Narratives on “Climate Refugees.”' Geoforum 45: 63-72. https://doi.org/10.1016/j. geoforum.2012.09.009.

Castree, Noel, et al.

2014 "Changing the Intellectual Climate." Nature Climate Change 4: 763-68. https:// doi.org/10.1038/nclimate2339.

Chaturvedi, Sanjay, and Timothy Doyle

2015 Climate Terror: A Critical Geopolitics of Climate Change. New York: Palgrave Macmillan.

Choi, Vivian

2015 “Anticipatory States: Tsunami, War, and Insecurity in Sri Lanka." Cultural Anthropology 30, no. 2: 286-309. https://doi.org/10.14506/ca30.2.09.

Collier, Stephen J., and Andrew Lakoff

2015 "Vital Systems Security: Reflexive Biopolitics and the Government of Emergency." Theory, Culture, and Society 32, no. 2: 19-51. https://doi.org/ 10.1177/0263276413510050.

Cons, Jason

2016 Sensitive Space: Anxious Territory at the India-Bangladesh Border. Seattle: University of Washington Press. 
Cross, Jamie

2013 "The Hundredth Object: Solar Lighting Technology and Humanitarian Goods." Journal of Material Culture 18, no. 4: 367-87. https://doi.org/10.1177/ 1359183513498959.

Cullather, Nick

2004 "Miracles of Modernization: The Green Revolution and the Apotheosis of Technology.” Diplomatic History 28, no. 2: 227-54. https://doi.org/10.1111/ j.1467-7709.2004.00407.x.

2010 The Hungry World: America's Cold War Battle Against Poverty in Asia. Cambridge, Mass.: Harvard University Press.

Debord, Guy

1995 The Society of the Spectacle. New York: Zone Books. Translated by Donald Nicholson-Smith. Originally published in 1967.

Dehaene, Michiel, and Lieven De Cauter, eds.

2008 Heterotopia and the City: Public Space in a Postcivil Society. New York: Routledge.

Duffield, Mark

2007 Development, Security, and Unending War: Governing the World of Peoples. Malden, Mass.: Polity.

2010 "The Liberal Way of Development and the Development-Security Impasse: Exploring the Global Life-Chance Divide.” Security Dialogue 41, no. 1: 53-76. https://doi.org/10.1177/0967010609357042.

Dunn, Elizabeth Cullen

2012 "The Chaos of Humanitarian Aid: Adhocracy in the Republic of Georgia." Humanity 3, no. 1: 1-23. https://doi.org/10.1353/hum.2012.0005.

Evans, Brad, and Julian Reid

2014 Resilient Life: The Art of Living Dangerously. Malden, Mass.: Polity Press.

Faubion, James D.

2008 "Heterotopia: An Ecology." In Heterotopia and the City: Public Space in a Postcivil Society, edited by Michiel Dehaene and Lieven De Cauter, 31-40. New York: Routledge.

Feldman, Shelley

2003 "Paradoxes of Institutionalization: The Depoliticization of Bangladeshi NGOs." Development in Practice 13, no. 1: 5-26. https://doi.org/10.1080/ 0961452022000037955.

Foucault, Michel

1998 “Different Spaces.” Translated by Robert Hurley. In Essential Works of Foucault: 1954 1984, Volume 2: Aesthetics, Methods, and Epistemology, edited by James D. Faubion, 175-86. New York: New Press. Originally published in 1984.

Friedman, Lisa

2009 “A Global 'National Security' Issue Lurks at Bangladesh's Border.” New York Times, March 23. http://www.nytimes.com/cwire/2009/03/23/23climate

Funk, McKenzie wire-a-global-national-security-issue-lurks-at-ba-10247.html.

2014 Windfall: The Booming Business of Global Warming. New York: Penguin.

Günel, Gökçe

2011 "A Flying Man, a Scuttled Ship, and a Timekeeping Device: Reflections on Ibn Battuta Mall.” Public Culture 23, no. 3: 541-49. https://doi.org/10.1215/ 08992363-1336408.

Gupta, Akhil

2015 “Is Poverty a Global Security Threat?" In Territories of Poverty: Rethinking North and South, edited by Ananya Roy and Emma Shaw Crane, 84-102. Athens: University of Georgia Press. 
Hall, Elizabeth F., and Todd Sanders

2015 "Accountability and the Academy: Producing Knowledge about the Human Dimensions of Climate Change." Journal of the Royal Anthropological Institute 21, Harris, Gardiner no. 2: 438-61. https://doi.org/10.1111/1467-9655.12162.

2014 "Borrowed Time on Disappearing Land: Facing Rising Seas, Bangladesh Confronts the Consequences of Climate Change." New York Times, March 28. http://www.nytimes.com/2014/03/29/world/asia/facing-rising-seas-

Hartmann, Betsy bangladesh-confronts-the-consequences-of-climate-change.html.

2010 "Rethinking Climate Refugees and Climate Conflict: Rhetoric, Reality, and the Politics of Policy Discourse." Journal of International Development 22, no. 2: 233-

Hashmi, Tej 46. https://doi.org/10.1002/jid.1676.

1992 Pakistan as Peasant Utopia: The Communalization of Class Politics in East Bengal, 19201947. Boulder, Colo.: Westview Press.

Hetherington, Kevin

1997 The Badlands of Modernity: Heterotopia and Social Ordering. New York: Routledge.

Hossain, E., S. M. Nurun Nabi, and A. Kaminski

2015 "Climate-Smart House: Housing that is Cyclone Resistant and Food, Energy, and

Water Efficient in Bangladesh." Penang, Malaysia: WorldFish. Program

Brief 2015-27. http://www.worldfishcenter.org/content/climate-smart-houseHossain, Naomi

housing-cyclone-resistant-and-food-energy-and-water-efficient-bangladesh.

2017 The Aid Lab: Understanding Bangladesh's Unexpected Success. New York: Oxford University Press.

Islam, Md Saidul

2014 Confronting the Blue Revolution: Industrial Aquaculture and Sustainability in the Global South. Toronto: University of Toronto Press.

Johnson, Peter

2006 “Unraveling Foucault's 'Different Spaces'.” History of the Human Sciences 19, no. 4: 75-90. https://doi.org/10.1177/0952695106069669.

Jones, Reece

2016 Violent Borders: Refugees and the Right to Move. New York: Verso.

Karim, Lamia

2011 Microfinance and Its Discontents: Women in Debt in Bangladesh. Minneapolis: University of Minnesota Press.

Keck, Frédéric, and Andrew Lakoff

2013 "Preface: Sentinel Devices." Limn, no. 3. http://limn.it/preface-sentineldevices-2.

Lakoff, Andrew

2008 "The Generic Biothreat, or, How We Became Unprepared." Cultural Anthropology

Lewis, David

23, no. 3: 399-428. https://doi.org/10.1111/j.1548-1360.2008.00013.x.

2011 Bangladesh: Politics, Economy, and Civil Society. New York: Cambridge University Press.

Lowe, Celia

2010 "Viral Clouds: Becoming H5N1 in Indonesia." Cultural Anthropology 25, no. 4: 625-49. https://doi.org/10.1111/j.1548-1360.2010.01072.x.

Martinez, Oscar

1994 Border People: Life and Society in the U.S.-Mexico Borderlands. Tucson: University of Arizona Press.

Marzec, Robert P.

2015 Militarizing the Environment: Climate Change and the Security State. Minneapolis: University of Minnesota Press. 
Masco, Joseph

2010 "Bad Weather: On Planetary Crisis." Social Studies of Science 40, no. 1: 7-40. https://doi.org/10.1177/0306312709341598.

Massumi, Brian

2015 Ontopower: War, Powers, and the State of Perception. Durham, N.C.: Duke University Press.

Mathews, Andrew

2014 "Scandals, Audits, and Fictions: Linking Climate Change to Mexican Forests." Social Studies of Science 44, no. 1: 82-108. https://doi.org/10.1177/ 0306312713490330.

McElwee, Pamela

2015 "From Conservation and Development to Climate Change: Anthropological Engagements with REDD+ in Vietnam." In Climate Cultures: Anthropological Perspectives on Climate Change, edited by Jessica Barnes and Michael R. Dove, 82105. New Haven, Conn.: Yale University Press.

O’Neill, Kevin Lewis

2015 Secure the Soul: Christian Piety and Gang Prevention in Guatemala. Oakland: University of California Press.

Orlove, Ben

2009 "The Past, the Present, and Some Possible Futures of Adaptation." In Adapting to Climate Change: Thresholds, Values, Governance, edited by W. Neil Adger, Irene Lorenzoni, and Karen L. O’Brien, 131-63. New York: Cambridge University Press.

Paprocki, Kasia

2015 “Anti-Politics of Climate Change.” Himal Southasian, November 30. http:// himalmag.com/anti-politics-of-climate-change-bangladesh.

2018 "Threatening Dystopias: Development and Adaptation Regimes in Bangladesh.” Annals of the American Association of Geographers, January 23. https://doi.org/ 10.1080/24694452.2017.1406330.

Paprocki, Kasia, and Jason Cons

2014 "Life in a Shrimp Zone: Aqua- and Other Cultures of Bangladesh's Coastal Landscape.” Journal of Peasant Studies 41, no. 6: 1109-1130. https://doi.org/ 10.1080/03066150.2014.937709.

Paprocki, Kasia, and Saleemul Huq

2018 "Shrimp and Coastal Adaptation: On the Politics of Climate Justice." Climate and Development 10, no. 1: 1-3. https://doi.org/10.1080/17565529.2017. 1301871.

Parenti, Christian

2011 Tropic of Chaos: Climate Change and the New Geography of Violence. New York: Nation Books.

Ramachandran, Sujata

1999 "Of Boundaries and Border Crossings: Undocumented Bangladeshi 'Infiltrators' and the Hegemony of Hindu Nationalism in India." Interventions 1, no. 2: 235-

Redfield, Peter 53. https://doi.org/10.1080/13698019900510331.

2012 "Bioexpectations: Life Technologies as Humanitarian Goods." Public Culture 24, no. 1: 157-84. https://doi.org/10.1215/08992363-1443592.

Roy, Pinaki

2014 “Still a Wasteland.” Daily Star, May 25. http://www.thedailystar.net/still-awasteland-25552.

Samimian-Darash, Limor

2016 "Practicing Uncertainty: Scenario-Based Preparedness Exercises in Israel." Cultural Anthropology 31, no. 3: 359-86. https://doi.org/10.14506/ca31.3.06. 
Samimian-Darash, Limor, and Meg Stalcup

2016 "Anthropology of Security and Security in Anthropology: Cases of Counterterrorism in the United States." Anthropological Theory 17, no. 1: 60-87. https: / / doi.org/10.1177/1463499616678096.

Shibly, Din Muhammad, and Hasan Mehedi

2015 A Tale from Climate Ground Zero: Climate Change, Land, and People in Bangladesh. Dhaka: COAST Trust.

Sloterdijk, Peter

2009 “Talking to Myself about the Poetics of Space." Harvard Design Magazine, no. 30. http: / / www.harvarddesignmagazine.org/issues/30/talking-to-myself-about-

Soja, Edward W. the-poetics-of-space.

1996 Thirdspace: Journeys to Los Angeles and Other Real-and-Imagined Places. Malden, Mass.: Blackwell.

Stepputat, Finn

2012 "Knowledge Production in the Security-Development Nexus: An Ethnographic Reflection.” Security Dialogue 43, no. 5: 439-55. https://doi.org/10.1177/ 0967010612457973.

Sur, Malini

2014 "Divided Bodies: Crossing the India-Bangladesh Border." Economic and Political Weekly 49, no. 13: 31-35. http://www.epw.in/journal/2014/13/ perspectives/divided-bodies.html.

Tanner, Thomas, et al.

2015 "Livelihood Resilience in the Face of Climate Change." Nature Climate Change 5: 23-26. https://doi.org/10.1038/nclimate2431.

Thankuria, Nava

2015 “Northeast India Faces Floods of Migrants.” Asia Sentinel, September 23. http:// www.asiasentinel.com/society/northeast-india-migrants.

van Schendel, Willem

2005 The Bengal Borderland: Beyond State and Nation in South Asia. New York: Anthem Press.

Vaughn, Sarah E.

2017 "Disappearing Mangroves: The Epistemic Politics of Climate Adaptation in Guyana." Cultural Anthropology 32, no. 2: 242-68. https://doi.org/10.14506/ ca32.2.07.

Walker, Jeremy, and Melinda Cooper

2011 "Genealogies of Resilience: From Systems Ecology to the Political Economy of Crisis Adaptation.” Security Dialogue 42, no. 2: 143-60. https://doi.org/ 10.1177/0967010611399616.

Watts, Michael

2014 "Resilience as a Way of Life: Biopolitical Security, Catastrophism, and the FoodClimate Change Question." In Bioinsecurity and Vulnerability, edited by Nancy N. Chen and Lesley A. Sharp, 145-72. Santa Fe, N.M.: School for Advanced Research.

Werrell, Caitlin E., and Francesco Femia, eds.

2017 Epicenters of Climate Security: The New Geostrategic Landscape of the Anthropocene. Washington, DC: Center for Climate and Security. https:// climateandsecurity.org/epicenters.

Whitington, Jerome

2016 "Modernist Infrastructure and the Vital Systems Security of Water: Singapore's Pluripotent Climate Futures.” Public Culture 28, no. 2: 415-41. https://doi.org/ 10.1215/08992363-3427511.

Yeh, Emily T.

2013 Taming Tibet: Landscape Transformation and the Gift of Chinese Development. Ithaca, N.Y.: Cornell University Press. 
Zee, Jerry

2017 "Holding Patterns: Sand and Political Time at China's Desert Shores." Cultural Anthropology 32, no. 2: 215-41. https://doi.org/10.14506/ca32.2.06.

Zeiderman, Austin

2016 Endangered City: The Politics of Security and Risk in Bogotá. Durham, N.C.: Duke University Press. 